\title{
Impact of Human Capital on the Organization's Innovative Capabilities: Case of Telecom Sector in Pakistan
}

\author{
*Samar Hayat Khan, Hassan Ahmed Shah, Abdul Majid, Muhammad Yasir \\ Hazara University Mansehra, Pakistan \\ *samar_hayat2010@yahoo.com
}

\begin{abstract}
The purpose of this study is to investigate the impact of human capital on organization's innovative capabilities in the narrative context of Pakistan. Today various organizations recognized the significance and importance of the intellectual capital. Without any doubt in knowledge-intensive organizations like telecom sector organizations intellectual capital plays a vital role in the contemporary aggressive and everchallenging business environment. The organizations can achieve competitive edge over its competitors by mean of innovation. By effective utilization of intellectual capital organizations can enhance innovative capabilities. Intellectual capital can be classified into three classifications named as human capital, structural capital and relational capital. Human capital is the main component of the intellectual capital and considered as a main aspect for the organization in order to perform in this diverse and unpredictable business environment. The conception of human capital now became mainstream issue for both academics and business practitioner all around the world. However, in the context of developing countries like Pakistan concept of human capital is still under explored. In this study at hand the impact of human capital organization's innovative capabilities i.e. radical and incremental innovative capabilities are examined. Three hypotheses were developed in order to test the relationship between human capital and innovative capabilities of telecom sector organization in Pakistan. To accomplish the objectives of this study survey method was used in which data was collected through questionnaire. Telecom Sector of Pakistan has been taken as unit of analysis. The collected data was analyzed with the help of SPSS by applying the correlation and regression test. Results of correlation and regression analysis showed that there is a strong relationship between human capital and organization's innovative capabilities in telecom sector of Pakistan and all three developed hypotheses were supported.
\end{abstract}

Keywords: Human Capital (HC), Innovative Capabilities, Radical Innovative Capabilities, Incremental innovative Capabilities, Telecom Sector of Pakistan

\section{Introduction}

The continuous variations in economic, political and socio-cultural environment are affecting businesses severely, and environment of business organizations are defined in term of unpredictably and uncertainty. The business organizations are trying to survive by coping unpredictability, and by adopting contemporary dimensions of change. There are various techniques to respond uncertainties and unpredictability of organizational environment in which innovation is one of them, Innovation is the application of knowledge to create new knowledge (Grant, 1996; Dean \& Kretschmer, 2007). It is accepted widely that organizational knowledge is the vital contributor to innovation. As the result of the emergent of knowledge management as new field, for studying that what required to be done to get most out from the knowledge resources of an organization by linking innovation and knowledge management. To compete in telecom sector, it is important for the organization to obtain organization specific human capital. Various research studies indicating knowledge resources of the organizations as intellectual capital of an organization has emphasizes on the belief that organizations utilized the knowledge in different ways. The various scholars of those studies conceive intellectual capital as the summation of organizational knowledge that is utilized by organizations for the purpose of competitive knowledge (Dean \& Kretschmer, 2007; Leitner, 2005; Johnson, Neave \& Pazderka, 2002). Nonetheless, how human capital acquires, collected and utilized stay disconnected to the particular kinds of organizational innovative capabilities own by organizations, with the majority studies only relating knowledge to common, in broader view defined outcomes of innovation like introducing new product, technology and revenue brought forth from new products (Subramaniam \& Youndt, 2005). Very few 
number of researchers emphasizes in their studies on examine the relationship between human capital and different innovative capabilities of an organization.

Especially in the context of business organization of Pakistan no such a study is found. Additionally, it is found that fundamentally different kind of knowledge required for radical and incremental innovative capabilities, incremental innovative capabilities needs the reinforcement of existing knowledge and radical innovative capabilities requires transformation of existing knowledge. A study of human capital in relationship to innovative capabilities of telecom sector organizations may provide a useful insight for the organizations working in said sector. The key rationale for the study at hand is extracting the literature on knowledge management and innovative capabilities to explore the main elements of human capital. Numerous studies focus on the influence of human capital on the innovative capabilities under the frame work of intellectual capital instead of discussing human capital on its own. So the conception of human capital in this study might be the starting point for the further studies on the management of human capital in the organizations. This study might also be helpful in further contributing in literature through classifying several concepts in to consolidating framework of the innovative capabilities in the telecom sector. This article starts with related literature on human capital and innovative capabilities, followed by theoretical framework, research methodology and finally discussing the findings and implications of the study. The main focus of research is on the impact of human capital on the innovative capabilities (radical \& incremental) and its benefits to telecom sector of Pakistan.

\section{Literature review}

Human capital is the sum of components that are related to organization employees such as employees knowledge, skills, abilities, capabilities, commitment, creativities, attitude and wisdom etc, and this capital is not owned by the business organization and its lost when the employee leave the organization (Chen, Lin \& chang, 2006). Sveiby (2001) argued that the human capital denotes to individual's ability to act in several circumstances that consist of education, skills, experience, motivation and values. Human capital is the worth that is provided by the organization's employees by applying their knowledge, skills, intellectual agility and proficiency (Barney, 1991). According to Isaac, Herremans and Kline (2010) and Bontis (1998) human capital is related to the employees of an organization (employee's knowledge, education, competence, skill, abilities and innovation).However it is agreed that employees create intellectual capital by the use of their competence, intellectual agility, attitude and ability. Human capital (HC) can be termed as the component of intellectual capital that includes the skills, knowledge, intellectual agility and attitudes of the employees of an organization (Roos, Roos, Dragonetti \& Edvinsson, 1997). According to Kang and Snell (2009) human capital can be perceived as a key instrument to any organization learning and to induce the skill of acquiring innovative knowledge. According to Berg (1969) that people with high level of skills and knowledge are the main source of the generations of new techniques and ideas that can be embodied in processes and production equipment; they induces the changes in the method of production and service delivery which enhanced the associations among the managers, employees and customers of the organization.

Organizations with knowledgeable, capable skilful and experienced employees would be the for the most part probable to generate new knowledge, because novel knowledge is built upon present knowledge. As a result, organization is required to build upon a workforce with a high level of specialized human capital to create novel knowledge. According to Stewart (1997) it was evident that human capital should be organization specific. Human capital is the mainly dynamic and employee related capital rests in the organization (Brooking, 1996). Human capital ought to contain capability (knowledge and skills), intellectual agility (innovation, imitation, adaptation and packaging) and attitudes (motivations and behaviors) (Roos et al., 1998). Lynn (2002) argued that human capital contain capabilities and skills own by the employees of the organization, it will craft and preserve the wealth for an organization and it is also a vital source of intellectual capital. Youndt et al. (2004) supposed that human capital was the investments made by the organization in talents and technologies that benefited competitive advantage through enhancing innovation.

Innovation: Before going to explore the literature about innovative capabilities it is necessary to described that what innovation is? Which has been remaining a regularly spoken topic for scientific literature specially, due to its application for an organization success and survival? Yet, the understanding and analysis of 
phenomenon 'Innovation' remains rising discussions (Subramaniam \& Youndt, 2005). According to Van de Ven (1986) innovation can be defined as object or practice that seems as new to the extent that it is employed in. It is the way to bring new ideas continuously into applied use and accumulating value to the organization. It is critical for individuals to possess necessary knowledge and skills for innovation. Galende (2006) argued innovation is the furthermost knowledge intensive organizational process that rest on an organization's individual members and shared knowledge.

Innovative capabilities: Terms like innovative capability, innovation capability and innovation found in the literature of innovation and has been used interchangeably to each other. Few of the researchers advocate that this has troubled the development of theory of innovation (Downs \& Mohr, 1976; Dewett, Whittier \& Williams, 2007), whereas, some of the others argued that the influence of this difference is nominal (Damanpour, 1991). Lawson and Samson in (2001) debated that innovative capability and innovation arise at diverse phases in the progression of innovation, in which innovative capability is an important factor in emerging out puts of innovation. In the literature different researchers argued about the term innovative capabilities in different ways. Innovative capabilities generally include the knowledge, skills and management practices required to craft modification and develop products/services, processes, equipment and business models (Norman, 1998). According to Wonglimpiyarat (2010) Innovative capability discusses the ability of an organization to brand key enhancements and changes to prevailing technologies and to build new technologies. Sher and Yang (2005) argued according to Resource based view of the organization, innovative capability is perceived as an important to an organization for accomplishing strategic competitiveness. Elmquist and Le Masson (2009) suggested that the innovative capability of an organization consist the ability of an organization to generate knowledge and new ideas to grape benefit of market openings and add value to organization. Innovative capabilities are normally classified as incremental and radical innovation capabilities (e.g., Dewar \& Dutton, 1986; Subramaniam \&Youndt, 2005). Radical innovative capability is to bring necessary and revolutionary changes in the existing practices or technology, and whereas, incremental innovative capability is bring to minor improvements in prevailing processes and technologies ( $0^{\prime}$ Reilly \& Tushman, 2004). Pavitt (1991) defines radical innovations as revolutionary or discontinuous changes, whereas incremental innovations are orthodox or modest additions in a line of chronological developments.

Herrmann, Gassmann and Eisert (2007) defines radical innovation as the tendency of an organization to bring together new products that integrate significantly different technology as compared to prevailing products and can satisfy customer needs either considerably superior than existing products, or fulfill different sorts of needs which could not be satisfied at all with present products. Subramaniam and Youndt (2005) argued the Incremental innovative capability is well described as the ability of organization to make novelties that augment and support prevailing products and services. On the other side, radical innovative capability is the ability of an organization to create innovations that considerably alter present products and services. The variance between incremental and radical innovative capabilities is centered on the type of knowledge used. Hall and Soskice (2004) discussed that the various skill outlines are associated to various type of innovative capabilities. Incremental innovative capabilities are expected more to be originated in synchronized market economies where employees of the organization have exceedingly industry or organization specific skills, while radical innovative capabilities are frequently originated in the market economies which are more liberal and where employees of the organization have a wide ranging skill profile

Human capital and innovative capabilities: Knowledge owned by employees and abilities are the key sources of innovation (Kang \& Snell, 2009; Wang \& Chang, 2005; Van Buren, 1998). However it is illustrated that it is suitable to construe that human capital closely affects the innovative capabilities of the organization. Employees are needed by an organization to carry out the inner procedures of an organization as well also required to perform its customer services, the process efficiency and customer satisfaction will be affected by employees by means of providing quality of service in executing inner procedures (Wang \& Chang, 2005). Various different studies already underlined that workforces with better education have wide ranging experience are more capable to contribute to organizational betterment as compared to other those are lesser in education and spend resources and time (Dakhli \& DeClercq, 2004). Schuler and Jackson (1987) argued that employee of the organization should be permitted to develop their skill while an innovative strategy which can also be helpful to use in performing other tasks of the organization. Prevailing broad knowledge could be used to cultivate entirely novel products and processes or to develop present ones. Kang 
and Snell (2009) discussed that area specific skills and knowledge can be linked to the further operational acquirement and incorporation of new, extensive knowledge in a slightly fine variety of constraints. The human capital would influence an organization's capabilities to craft new knowledge. Cohen and Levinthal (1990) suggested that the level and specialness of knowledge presently held by an employee possibly will either smooth the progress of or limit the degree to which new information could be understood, integrated and absorbed.

As a result, an organization with a high level of human capital would ultimately direct to a superior capability of individuals to learn and integrate new knowledge to which they were exposed. It was anticipated that the overlapping among new and preceding knowledge encouraged employees to relate and link the both kinds of knowledge, and lead the individual to create new knowledge. A significant part of the skills and knowledge essential for innovation resides with and it is utilized by individuals. Hence, we suppose that human capital enhances the transformation or reinforcement the existing knowledge and by this means influences innovative capabilities of an organization (Hill \& Rothaermel, 2003). Human capital is considered as the vital element of intellectual capital for the base of the all innovation procedures. An organization which is gifted with brilliant, experienced and motivated employee would be more innovative as compared to its competitors. In the view of Snell and Dean (1992) human capital is the intellectual capital's type which is considered as the major cause of new knowledge and ideas. According to Subramaniam and Youndt (2005) human related assets are critical for increasing the capacity of an organization to absorb and deploy new and different knowledge domains, and exposing an organization to new technology. According to Nonaka and Takeuch (1995) and Hill and Rothaermel (2003) organizational routines are generally established by highly trained and motivated employees; therefore, human capital becomes critical while pushing the organization to its technological edges, creating the greatest encouragement to obtain new knowledge and innovations. In this way it make sense that organization having best human capital as compared to its competitors would craft the more new ideas and product/services in comparison to its competitors. Human capital being the main source for new knowledge and ideas helps the organizations in the development of radical and incremental innovations.

Theoretical Framework: The basic validation in favor of our framework was that the key attributes of human capital has a particular transmuting or reinforcing influence on knowledge. Nevertheless, this influence is not all the time isolated. That human capital intertwined in organizations. Thus human capital plays an important role in shaping the innovative capabilities of information. Hence, we embedded our research framework in the premise that human capital reinforce or transform knowledge to selectively influence radical and incremental innovative capabilities.

\section{Figure 1: Theoretical Framework}

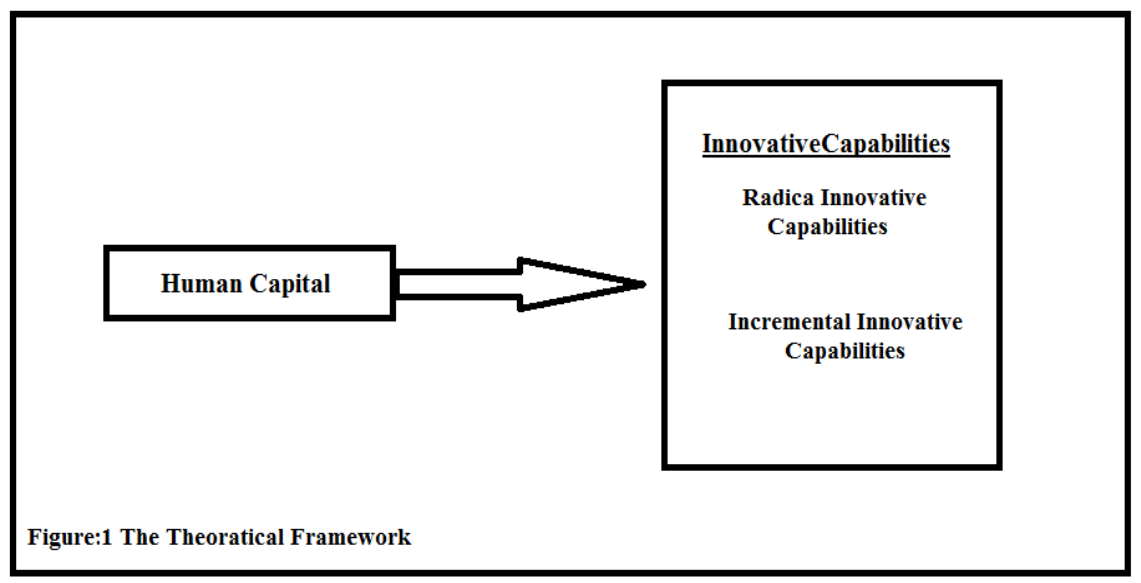

The following hypotheses were formulated based on the theoretical framework. These hypotheses include a main hypothesis with two sub hypotheses:

HA: The human capital has positive impact on the innovative capabilities of the organization in telecom sector of Pakistan. 
Ha1: The human capital has positive impact on the radical innovative capabilities of the organization in telecom sector of Pakistan.

Ha2: The human capital has positive impact on the incremental innovative capabilities of the organization in telecom sector of Pakistan.

\section{Methodology}

The current study at hand is quantitative in nature. Data was collected by using survey method by formulating the questionnaires which were distributed among the respondents of the selected organizations working in telecom sector of Pakistan. Cellular services providing companies working in telecom sector of Pakistan was taken as the unit of analysis. There were five cellular companies working in Pakistan which are Mobilink, Ufone, Telenor, Warid and Zong. The entire population for this study based on the employees working in the head offices of Mobilink, Ufone, Telenor, Warid and Zong based in Islamabad. The head offices of Mobilink, Ufone and Telenor were selected randomly as a sample for this research. The questionnaire was based on the 22 items in which 13 items assessing human capital and nine items assessing innovative capabilities (radical and incremental innovative capabilities). 13 items assessing human capital were adopted and modified which were based on the discussions surrounding human capital and contemporary strategic human resource management studies of Snell and Dean (1992) and Schultz (1961) and comprises of the overall skill, expertise and knowledge levels of the employees in an organization. Our measures for the two types of innovative capabilities were adopted and modified accordingly from the discussions of Henderson and Clark (1990) and Tushman and Anderson (1986). The measure of incremental innovative capability was a four-item scale assessing capability of an organization to extend and reinforce its existing product, service and expertise. Correspondingly, radical innovative capability was measured with a five-item scale analyzing the capability of an organization to make existing product, service lines and expertise obsolete. The aim of questionnaire is to develop greater knowledge of human capital and innovative capabilities in Pakistan, more specifically to confirm the objectives of the study.

\section{Results and Discussion}

A total of 200 questionnaires distributed within the employees of cellular services providers organizations. 117 out of 200 useable questionnaires were returned. Data was screened and cleaned. The response rate was found satisfactory. Information regarding the demographic of the respondents was also gathered in this study in hand. Inferential statistics techniques correlation and regression analysis were utilized to develop the link between human capital and innovative capabilities. Cronbach Alpha analysis was used to find the reliability of the instrument. The Cronbach Alpha's value for the measuring instrument was 0.891which depicted that the instrument was reliable. The Cronbach Alpha's value for each construct was also tested which showed the Cronbach Alpha's value for human capital, radical innovative capabilities and incremental innovative capabilities were $0.875,0.794$ and 0.834 respectively. Correlation and regression analysis were utilized to develop the link between human capital and innovative capabilities

\section{Table 1: Pearson Correlations}

\begin{tabular}{|c|c|c|c|c|}
\hline $\begin{array}{l}\text { Innovative } \\
\text { Capabilities }\end{array}$ & $\begin{array}{ll}\begin{array}{l}\text { Innovative } \\
\text { Capabilities }\end{array} & \text { Human Capital } \\
\end{array}$ & Radical & & Incremental \\
\hline Human Capital & $\begin{array}{l}\text { Pearson Correlation } \\
\text { Sig. (2-tailed) } \\
\text { N }\end{array}$ & $\begin{array}{l}1 \\
117\end{array}$ & & \\
\hline $\begin{array}{l}\text { Radical innovative } \\
\text { Capabilities }\end{array}$ & $\begin{array}{l}\text { Pearson Correlation } \\
\text { Sig. (2-tailed) } \\
\text { N }\end{array}$ & $\begin{array}{l}.872^{* *} \\
.000 \\
117\end{array}$ & $\begin{array}{l}1 \\
117\end{array}$ & \\
\hline $\begin{array}{l}\text { Incremental Innovative } \\
\text { Capabilities }\end{array}$ & $\begin{array}{l}\text { Pearson Correlation } \\
\text { Sig. (2-tailed) } \\
\mathrm{N}\end{array}$ & $\begin{array}{l}.748^{* *} \\
.000 \\
117\end{array}$ & $\begin{array}{l}.754^{* *} \\
.000 \\
117\end{array}$ & $\begin{array}{l}1 \\
117\end{array}$ \\
\hline
\end{tabular}


The above table 1 depicts that there is a positive relationship between human capital and the two types of innovative capabilities (radical and incremental innovative capabilities). The Pearson Correlation Coefficients results at. $.872^{* *}$ and $.748^{* *}$ respectively, underline that there is strong positive correlations exist between human capital, radical innovative capabilities and incremental innovative capabilities. These results advocate that strong human capital will significantly influenced the innovative capabilities of the business organizations. Results or regression analysis are represented by able 2, 3, 4 and 5 .

Table 2: Multiple Regression Analysis

\begin{tabular}{lllcc}
\hline Modle & R & R-Square & Adjusted R Square & Std. Error of the Estimate \\
\hline 1 & $.972^{\mathrm{a}}$ & .745 & .695 & .05861 \\
\hline
\end{tabular}

Table 3: Cofficient Unstandardized Coefficients Standardized Coefficients

\begin{tabular}{lllllll}
\hline Modle & & B & Std. Error & Beta & t & Sig. \\
\hline 1 & Constant & .556 & .098 & & 5.663 & .000 \\
& Human capital & .881 & .020 & .772 & 44.557 & .000 \\
\hline
\end{tabular}

a. Dependent Variable: Radical Innovative Capabilities

The above Table 2 and 3 depicted the regression analysis for predicator human capital and dependent variable radical innovative capabilities. The table showed that .745 or $74.5 \%$ of the variance in dependent variable (radical innovative capabilities) was contributed by human capital. It was also eminent that the contribution by independent variables such as human capital in the explanation the dependent variable (radical innovative capabilities) is .772 as given in the table 2a under standerdized coefficients, beta. The beta value for human capital is .772 and value of $p$ is $.000<.005$, which suggest the statistically significant relationship between the variables human capital and radical innovative capabilities with $\mathrm{p}$ value less than .005 .

Table 4: Multiple Regression Analysis

\begin{tabular}{lllcc}
\hline Modle & R & R-Square & Adjusted R Square & Std. Error of the Estimate \\
\hline 1 & $.748^{\mathrm{a}}$ & .560 & .556 & .20361 \\
\hline
\end{tabular}

Table 5: Coefficient Unstandardized Coefficients Standardized Coefficients

\begin{tabular}{llccccc}
\hline Modle & & B & Std. Error & Beta & t & Sig. \\
\hline 1 & Constant & .692 & .341 & & 2.028 & .045 \\
& Human capital & .831 & .069 & .448 & 12.094 & .000 \\
\hline
\end{tabular}

a. Dependent Variable: Incremental Innovative Capabilities

The above Table 4 and 5 showed the regression analysis for predicator human capital and dependent variable incremental innovative capabilities. The table showed that.560or $56 \%$ of the variance in dependent variable (incremental innovative capabilities) was contributed by human capital. It was also clear from the table that the contribution by independent variables such as human capital in the explanation the dependent variable (incremental innovative capabilities) is .448 as given in the table $2 c$ under standardized coefficients, beta. The beta value for human capital is .448 and value of $p$ is $.000<.005$, which suggest the statistically significant relationship between the variables human capital and radical innovative capabilities with $\mathrm{p}$ value less than .005 .

\section{Conclusion}

The main aim of this study in hand was to discover the role of human capital in influencing the organizational innovative capabilities i.e. radical and incremental innovative capabilities of cellular companies in telecom sector of Pakistan. During the course of this study it was eminent that the largest part of the respondents was familiar with the terms human capital and innovative capabilities. Grounded on previous studies, the human capital was anticipated to influence positively the innovative capabilities of the organization. The output results provided in tables1, 2, 2.1, 2.2 and 2.3 highlighted that there is a positive and significant relationship 
exist between the human capital and radical and incremental innovative capabilities of organization of telecom sector in Pakistan. The findings also indicated that organizations with strong human capital are more innovative as compare to other organizations. This is in line with Subramaniam and Youndt (2005) who founded that human capital is critical component of intellectual capital for innovation. The findings demonstrated that human capital can be used to mobilize, assemble, and manage in order to enhance organizational performance through innovation, and this coincide with the findings of other studies (Bontis et al., 2000; Sharabati et al., 2010). Unquestionably, human capital has contribution in enhancement of innovative capabilities of organization of telecom sector of Pakistan. Moreover, this finding enhances intellectual capital theory by demonstrating that intellectual capital has significant positive relationship with organizational performance. It is recommended for the business managers of the organizations could attain benefits like the competitive advantage by enhancing innovative capabilities through strong human capital. Finally, this research will be a milestone for future research in this area, particularly in Pakistan. In last for future research it is recommended that future research should undertake to confirm the findings of this study in other sectors of the industry.

\section{References}

Barney, J. (1991). Firm resources and sustained competitive advantage. Journal of Management, 17(1), 99120.

Berg, I. (1969). Education and jobs: The great training robbery. New York: Praeger.

Bontis, N. W., Keow, Y. \& Richardson, S. (2000). Intellectual capital and the nature of business in Malaysia. Journal of Intellectual Capital, 1(1), 85-100.

Bontis, N. (1998). Intellectual Capital: An Exploratory Study that Develops Measures and Models. Management Decision, 36(2), 63-76.

Brooking, A. (1996). Intellectual capital. London: International Thomson Business Press.

Chen, Y. C., Lin, M. J. J. \& Chang, C. H. (2006).The Influence Of Intellectual Capital On New Product Development Performance- The Manufacturing Company of Taiwan an Example. Total Quality management, 17(10), 1323-1339.

Cohen, W. \& Levinthal, D. (1990). Absorptive Capacity: A New Perspective on Learning and Innovation. Administrative Science Quarterly, 35(1), 128-152.

Dakhli, M. \& DeClercq, D. (2004). Human capital, social capital and innovation: a multi country study. Entrepreneurship \& Regional Development, 16(2), 107-128.

Damanpour, F. (1991). Organizational innovation: A meta-analysis of effects of determinants and moderators. Academy of Management Journal, 34(3), 555-590.

Dean, A. \& Kretschmer, M. (2007). Can Ideas be Capital? Factors of Production in the Postindustrial Economy: A Review and Critique. Academy of Management Review, 32, 573- 594.

Dewar, R. D. \& Dutton, J. E. (1986). The adoption of radical and incremental innovations; An empirical analysis. Management Science, 32(11), 1422-1433.

Dewett, T., Whittier, N. C. \& Williams, S. D. (2007). Internal diffusion; The conceptualizing of innovation implementation, Competitive Review. An International Business Journal, 17(1), 8-25.

Downs, G. W. J. \& Mohr, L. B. (1976). Conceptual issues in the study of innovation. Administrative Science Quarterly, 21(4), 700-714. innovations; An empirical analysis. Management Science, 32(11), 14221433.

Druker, P. (1999). Management challenges for the 21st century. New York: Harper Collins Publishers.

Elmquist, M. L. \& Masson, P. (2009). The value of a failed R\&D project: an emerging evaluation framework for building innovative capabilities. R\&D Management, 39(2), 136-152

Galende, J. (2006). Analysis of Technological Innovation from Business Economics and Management. Technovation, 26, 300-311

Grant, R. M. (1996). Toward a knowledge-based theory of the firm. Strategic Management Journal, 17, 109122.

Hall, P. \& Soskice, D. (2004). Varieties of Capitalism. The Institutional Foundations of Comparative Advantage. Oxford; University Press.

Henderson, R. \& Clark, K. B. (1990). Architectural innovation: The reconfiguration of existing product technologies and the failure of established firms. Administrative Science Quarterly, 35, 9-30. 
Herrmann, A., Gassmann, O. \& Eisert, U. (2007). An Empirical Study of the Antecedents for Radical Product Innovation and Capabilities for Transformation. Journal of Engineering and Technology Management, 24(1-2), 92-120.

Hill, C. W. L. \& Rothaermel, F. T. (2003). The Performance of Incumbent Firms in the Face of Radical Technological Innovation. Academy of Management Review, 28(2), 257-274

Isaac, R. G., Herremans, I. M. \& Kline, T. J. (2010). Intellectual Capital Management Enablers: A Structural Equation Modeling Analysis. Journal of Business Ethics, 93(2).

Johnson, L. D., Neave, E. H. \& Pazderka, B. (2002). Knowledge, Innovation and Share Value. International Journal of Management Review, 4, 101-134.

Kang, S. C. \& Snell, S. A. (2009). Intellectual capital architectures and ambidextrous learning; A framework for human resource management. Journal of Management Studies, 46(1), 65-92.

Lawson, B. \& Samson, D. (2001). Developing innovation capability in organizations; A dynamic capabilities approach. International Journal of Innovation Management, 5(3), 377-400.

Leitner, K. (2005). Managing and reporting intangible assets in research technology organizations. $R \& D$ Management, 35(2), 125-36.

Lynn, M. (2002). The ROI of human capital. HR Professional, 19(4), 34-45.

Nahapiet, J. \& Ghoshal, S. (1998). Social capital, intellectual capital, and the organizational advantage. Academy of Management Review, 23(2), 242-266.

Nonaka, I. \& Takeuchi, H. (1995). The Knowledge-Creating Company; How Japanese Companies Create the Dynamics of Innovation. New York; Oxford University Press.

Norman, D. A. (1998). The Invisible Computer (Cambridge, Massachusetts).MIT Press.

O’Reilly, C. A. \& Tushman, M. L. (2004).The ambidextrous organization. Harvard Business Review, 82(3), 7481.

Pavitt, K. (1991). What Makes Basic Research Economically Useful? Research Policy, 20(2), 109-120.

Roos, J. G., Roos, N., Dragonetti, K. \& Edvinsson, L. (1997). Intellectual Capital; Navigating the New Business Landscape. London: MacMillan Press.

Roos, J., Roos, G., Edvinsson, L. \& Dragonetti, N. C. (1998). Intellectual capital-navigating in the new business landscape. New York: New York University Press.

Schuler, R. S. \& Jackson, E. J. (1987). Linking competitive strategies with human resource management practices. The academy of management executives, 1(3), 207-219.

Schultz, T. W. (1961). Investment in human capital. The American Economic Review, 2(1), 1-17.

Sharabati, A. A., Jawad, N. \& Bontis, (2010). Intellectual capital and business performance in the pharmaceutical sector of Jordan. Management Decision, 48(1), 76-88.

Sher, P. J. \& Yang, P.Y. (2005).The effects of innovative capabilities and R\&D clustering on firm performance; the evidence of Taiwan's semiconductor industry. Technovation, 25(1), 33-43.

Snell, S. A. \& Dean, J. W. J. (1992). Integrated Manufacturing and Human Resource Management: A Human Capital Perspective. Academy of Management Journal, 35(2), 467504.

Stewart, T. A. (1997). Intellectual capital. New York: Doubleday-Currency.

Subramaniam, M. \& Youndt, M. A. (2005). The influence of intellectual capital on the types of innovative capabilities. Academy of Management Journal, 48(3), 450-463.

Sveiby, K. E. (2001). A knowledge-based theory of the firm to guide in strategy formulation. Journal of Intellectual Capital, 2(4), 344-58.

Tushman, M. \& Anderson, P. (1986). Technological discontinuities and organizational environments. Administrative Science Quarterly, 31, 439-65.

Van de Ven, A. H. (1986). Central Problems in the Management of Innovation. Journal of Management Science, 32(1), 590-607.

Van-Buren, M. (1998). Virtual coffee klatch. Technical Training, 9(5), 42-58.

Wang, W. Y. \& Chang, C. (2005). Intellectual capital and performance in causal models Evidence from the information technology industry in Taiwan. Journal of Intellectual Capital, 6(2), 222- 236.

Wonglimpiyarat, J. (2010). Innovation index and the innovative capacity of nations. Futures, 42(3), 247-253.

Youndt, M. A., Subramaniam, M. \& Snell, S. A. (2004). Intellectual capital profiles: An examination of investments and returns. Journal of Management Studies, 41(2), 335-362. 